\title{
Between Care and the Ethics of Utility: Towards a Better Human Social Relationship
}

\author{
Justina 0. Ehiakhamen \\ Department of Philosophy, Faculty of Arts, Ambrose Alli University, Ekpoma, Nigeria \\ Email: joehiakhamen@gmail.com
}

Received 13 March 2014; revised 13 April 2014; accepted 20 April 2014

Copyright (C) 2014 by author and Scientific Research Publishing Inc.

This work is licensed under the Creative Commons Attribution International License (CC BY). http://creativecommons.org/licenses/by/4.0/

(c) (i) Open Access

\begin{abstract}
Michael Schluter and David Lee among other scholars decry the extent of erosion in genuine personal relationships among human persons in present day societies. The concern it generates is consequent upon the social ills prevalent among humankind ranging from corruption, poverty, unemployment, armed robbery, kidnapping (adult napping), human trafficking, drug trafficking, internet fraud, ritual killings, conflicts, wars and a host of others. The wave of these social vices has been identified as a moral problem, which emanates from failure of the human person to develop a strong moral sense in present-day society with the emergence of democracy and market economy. This is so because if principles of moral actions are socially weak, they are usually unable to ensure a healthy inter-personal relationship as well as a healthy society. Given this backdrop, the paper attempts to interrogate the social import of an ethic of utility and care in order to come to terms with which would foster social relationships in contemporary society for the achievement of human well-being, viable and sustainable development.
\end{abstract}

\section{Keywords}

Humanity; Ethics; Utility; Care; Poverty; Social Relationships

\section{Introduction}

Society is meaningful not without humankind who is the subject and object of social interaction. The nature of human person bestores on him/her the burden of necessarily relating with one another, without which survival becomes difficult if not impossible. It is in the quest to meet human essential needs and desires for meaningful existence that interactions become unavoidably an essential apparatus for living a social life. Also necessary is the need to achieve a healthy society through a healthy human social relationship. Human person by nature is unknown to be an epitome of a systematize relationship with others that could generate a healthy society 
(Hobbes, 1909; Locke, 1970), hence, the onus falls on humankind to consciously fashion out a means of enhancing the ability to relate with one another in a productive manner for the realisation of human welfare and, social peace and harmony. This effort prompts ethical deliberations that culminate in ethical principles.

However, the effectiveness of a moral principle in establishing a sense of unity among persons is a function of how socially strong that moral principle is. This means if a principle is socially weak, it would be unable to ensure the kind of social relationship that can generate social solidarity among humankind. It is in the light of this that this paper attempts to look critically at the principle of utility and care ethics as ethical models with a view to determining which of them could be more adequate for humanity in the realisation of social aspirations, needed for a healthy and meaningful social relationship.

An ethical principle is utilitarian if it considers ends as the sole determinant of ethical good (Sahakian, 1974: p. 28). Utilitarianism is one of the dominant traditional moral theories since the eighteenth century which falls within the class of consequentialist ethical model. Consequentialism is the claim that morally right and wrong actions are purely a function of the consequences of such actions. By implication, no action is intrinsically right or wrong, rather, it is the consequences of an action that determine its rightness or wrongness. Utilitarianism is a kind of ethical empiricism which is somewhat oppose to deontology which is a kind of ethical rationalism. According to J. S. Mill, utilitarianism can be regarded as a theory that interprets moral value in terms of the usefulness of an action in promoting the greatest good interpreted as pleasure for the greatest number (Jacquette, 2004: p. 318).

On the other hand, there are frequently two senses in which care can be understood in ethical domain. The first sense is to "care for", the second, is to "care about". To "care about" requires the ability to consider the needs of both self and others, and to be responsible to both. This implies that questions' pertaining to what is right and best, and about what will meet the needs of others weigh equally in decision making process (Leffers, 1993: p. 66). To "care for" means responding to the particular, concrete, physical, spiritual, intellectual, psychic and emotional needs of others (and self) (Tronto, 1989: p. 34). Care as a model of ethics touches on the need to meet the deepest aspect of man's yearning for social good for the generality of people. Care ethics does not weigh the consequences of action over motives and intensions and vice versa, rather, an action is good when it appropriates productive tendency in terms of motives and consequences for humankind in general.

A more detailed explication of these moral theories—utilitarianism and care ethics is essential in order to unravel which is more adequate for enhancing social relationships among humans.

\section{The Ethics of Utility}

Utilitarian ethics originated from the writings of Jeremy Bentham (1748-1832) and John Stuart Mill (18061873), but was later given a wide discussion in contemporary versions. Utilitarian moral theory recognises or adopts "The Principle of Utility" (Mill, 1994: p. 201). It holds the view that the right act is that which produces the greatest amount of pleasure or happiness with the least amount of pain. Actions are solely motivated on their consequential benefits. Utilitarianism is therefore a brand of teleological or consequentialist ethics. The principle of utility has several formulations in Bentham and Mill, as well as in subsequent utilitarians; such includes:

The morally best (or better) alternative is that which produces the greatest (or greater) net utility, where utility is defined in terms of happiness or pleasure (Mackinnon, 1998: p. 34).

We ought to do that which produces the greatest amount of happiness for the greatest number of people (Mackinnon, 1998: p. 34).

It is presupposed that from these formulations we are able to determine a better or best action out of two or more actions, in terms of the happiness or pleasure produced by each. Utilitarianism also admonishes the moral agent to consider not only the alternatives available at the moment, but other possible choices, to get the best possible action. Utilitarianism has a peculiar character as it bases the moral standard of right and wrong on the consequential benefits of actions. According to utilitarians, human acts or practices should not be determined or assessed on the nature of the acts or the motive for which people do what they do. As Mill puts it; "He who saves a fellow creature from drowning does what is morally right, whether his motive be duty or the hope of being paid for his trouble" (Mackinnon, 1998: p. 34).

From experience however, there are conflicting pleasures. How then do we know the pleasure that should be preferred? To answer this question, Bentham provided us with the hedonistic calculus which is to serve as a guideline for a preferable pleasure among alternatives. The hedonistic calculus consists of seven criteria for de- 
ciding what kind of pleasure should be chosen. They are: intensity, duration, certainty, propinquity, fecundity, purity and extent. In all, what is of utmost importance to Bentham is the greatest balance of pleasure over pain. This is because according to Bentham, "Nature has placed mankind under the governance of two sovereign masters; pain and pleasure" (Bentham, 1961: p. 1) They dictate what we ought to do, what we do and what we shall do. Although J. S. Mill agrees with Bentham that the more pleasure or happiness the better, Mill, however, has a reservation for the quality of pleasure involved. Mill charges that the quality of pleasure should also count because some pleasures are better than others. For example, intellectual pleasures are more valuable in themselves than purely sensual pleasures such that it is better to be Socrates dissatisfied than a fool satisfied.

Worthy of note is that while the classical utilitarians: Bentham and Mill emphasised the hedonistic aspect of utility that the only thing that is intrinsically good is pleasure or happiness, some contemporary utilitarians (e.g. Rashdal, Hasting and G. E. Moore) are not hedonistic. They hold that other things besides pleasure are intrinsically good, e.g. Knowledge, peace, freedom, education, beauty or power. For them, these are goods to be maximised. Thus, utilitarians differ about what is good or evil or about what utility and welfare represent. These differences run through the scope of utilitarianism. Although two forms of utilitarianism are often discussed, William Frankena (1973: p. 35) the American moral philosopher, distinguishes between three kinds; Act, General and Rule utilitarianism.

We do not intend to give detailed elucidation of these kinds. However, in a nutshell, though these three forms of utilitarianism are different by virtue of the fact of differences in the object to which the utility principle can be applied, they are, however, similar because they use the same principle of evaluation to determine what is good or bad. In other words, these forms of utilitarianism are alike in requiring us to produce the greatest amount of happiness or pleasure (in all the senses identified) for the greatest number of people. However, they differ only on what the consequence should reside on. For act utilitarianism, it argues that we ought to consider the consequences of each act separately. General utilitarianism states that we ought to consider the consequences of the general practice. Rule utilitarianism holds that we ought to consider the consequences of the rule in general (Frankena, 1973: p. 35).

\section{The Ethics of Care}

Care ethics, without much dispute has been regarded as one of the most recent alternative theories in normative ethics, which seeks to lay down ethical principles to determine the terms of human social relationships for the welfare of any society. Care ethics was first given attention by Carol Gilligan, a psychologist, in 1982, in a work entitled In a Different Voice, with the aim to drive home the point that feminine values, such as emotions, feelings, attention, respect, attachment, responsiveness, responsibility, compassion, empathy, etc., can be sources of human social strength that could generate peaceful co-existence. What then is care ethics? Care as it relates to ethics is the ability to consider the needs of both self and others, and be responsible to both (Leffers, 1993: p. 66). This implies that questions about what is right and best, and about what will meet the needs of others weigh equally in decision making process. This is the sense in which Gilligan considered care ethics as an attempt to "care about" others and oneself.

However, Nel Noddings feared the limit of "care about" as it may not translate into "care for" which ought to be the essence of "care about". Noddings pointed out that it is possible to "care about" others without actually caring for them, this kind of care hangs at the level of good intentions and favourable disposition to helping others. She notes that being favourably disposed to caring for others is only a necessary process in care ethics which actualizes in conscious and deliberate efforts to help others attain their objectives and desires. In this regard, Tronto defines care ethics from the perspective to "care for", which involves responding to the particular, concrete, physical, spiritual, intellectual, psychic and emotional needs of others (and oneself) (Tronto, 1989: p. 34). Therefore, "care about" and "care for" give a comprehensive insight to care ethics as a moral approach to determine what is morally right and best to do. In the first sense (care-about) it expects mankind to be receptive to a broader horizon of all humans, that is, developing the virtue or willingness to care about others as human beings like you. In the second sense, it is an expression of natural inclination to attend to those who are close to us; hence Noddings (2002) argues that real care must be limited to individual's environment; as she affirms that charity begins at home. In this regard, Noddings conceives care as a transaction involving the direct face-to-face attempt to respond to the needs of a cared-for (Noddings, 2003: p. xvi). Care ethics involves the ability to respond in a network of relationship, which means ethical care involves practical and concrete actions, actual help, 
consciously embarked on to improve the cared-for in such a way which will enable him/her develop his/her capabilities for self determination (Oladipo, 2008: p. 6).

What then are the cardinal points of care ethics? Care ethics flourishes in such values as responsibility, feelings, respect, reliability, responsiveness, empathy, attentiveness, concreteness, etc. Care largely involves responsibility. It means accepting that one has positive duties concerning the welfare of others. The government which provides social welfare for her citizens discharges her responsibilities as well as the graduate applicant who refuses to join a ganged of robbers to terrorize other citizens. For care ethicists, feelings are indispensable factor of morality. When in ones' action, one considers the harm it would do to the other and refrain from it; one is seen to put feelings into action. Care taps its root from empathy which draws care from a more natural basis of sharing same nature. It involves the ability to share, understand and appreciate the feelings of others who are not necessarily within intimate relationship with us but simply because they are members of the same family of humanity. Moral respect presupposes that we refrain from hurting people or not play down on people self-esteem and integrity. Care ethics takes moral relationship from the level of abstraction to the level of moral actions having direct bearing on individual social productivity. Ethical concreteness emphasises on our sensitivity to complexity, connection, particularity and ambiguity as necessary condition which will ensure that we live together socially and politically. Above all there must be trust for the network of care to be reliable and sustainable. These are social nexus that make people remain in lifelong relationships. Because when actions are propelled on these values relationship is strengthened and viable society becomes inevitable.

The need to help people grow arises from the conception of the nature of the human person as a social being who lives and survives only in relation with others, an interdependent being, whose efforts alone are insufficient. In other words, care ethics conceives human beings in relational terms. Annette Baier (1988: p. 44) notes the first precept of care ethics to be based on the understanding that social relationships encompass a connection of humans as interdependent "second order". This means every social being needs care and has the ability to care for others. By implication, the society is divided not between two groups of people the "cared-for" and "caregiver", rather, it is a society of interdependence, in which everybody has something to benefit as well as something to contribute to the development of others. What is ethically right and best is to care for others and self. The formulation could be put thus: "I am under obligation to care about and for others, if I want to be moral" (Noddings, 2003: p. 79). In this way a sense of moral responsibility would be developed among mankind and a viable and suitable society could therefore emerge from the practice of care ethics, since the imperative is to care for somebody. Everybody is therefore charged with the responsibility of caring for somebody so as to ensure human development and peaceful coexistence.

\section{Enhancing Social Relationships: The Role of Care Ethics}

The aim of the paper has been to show which of the two moral theories examined above could foster social relationships and implant unity among humans given the fact that some moral values are less socially productive than others in ensuring human social integration. It is that some moral precepts are better able to bind people together in lifelong relationships than others. It is therefore expedient to encourage and propagate what binds humans together rather than what separates them as a measure to eliminate crime and enthrone social reproduction and development.

To this extent and from the foregoing, care ethics, given its precepts appears to have social impetus stronger than utilitarian principle in terms of generating a committed sense of unity among mankind. This is exemplified in their various claims regarding what should determine human relationship, what the measure of good and evil should be. For instance, utilitarianism is premised on utility as the sole determinant of what good and bad action should be. It is that pleasure should unreservedly be pursued at the expense of pain in so far as the pleasure is for the greatest number of people. There are a number of social danger in the application of the principle of utility as a measure of moral good; on the one hand, pleasure being the means and end of actions for a possible number of people fails to take humanity as a whole into consideration. Ultimately pleasure is the primary reason for action; such that an action with higher sum of pleasure distributable to a fewer number of people would be preferred over an action with lesser pleasure distributable to a greater number of people. Given human nature, the tendency to narrow down pleasure to individual level in the hedonistic sense is apparent, such that individuals seek their own pleasure alone. Pleasure seeking people are usually unable to care for others as much as themselves. This attitude can and has prompted social conflicts of various magnitudes and lack of readiness on the part of 
citizens to be responsible to their society. The point being made here is that since pleasure is the ultimate reason for action, the number of beneficiaries is less important. A. O. Echekwube (1999: p. 35) has argued in this vein that pleasure seeking people usually ignore and undermine the interests of others, a situation which promotes injustice as prevalent in the present-day society.

On the other hand, consequentialist theories into which utilitarianism falls are susceptible to a fundamental error of stating that "the end justifies the means" (Machiavelli, 1999) without reference to whether or not the means is justified. This explains the reason why a kidnapper or "adultnapper" could take his victim for ransom without thought for the pleasure of the victim. On a wider scale, consequentialist motive for action is unrealistic; for it can give moral credibility to immoral actions solely on the ground of pleasure promoted. In political domain, utilitarian attitude can be responsible for sidelined voices, perspectives, needs, etc.; which have occasioned endemic social conflicts in most parts of the globe. Corrupt leaders delight in operating the principle of utility by satisfying themselves and their hangers-on as constituting the majority. This is most unfortunate because when social ideals are eroded by self seeking behaviour, it is difficult for any society to survive.

This is also where care ethics marks a departure from utility principle, as care ethics focuses on fundamental issues of human survival as a prerequisite for self determination. Care meets not only our moral needs but also our psychological needs as a basic natural condition for human flourishing. Daniel Engster (2008: p. 2) demonstratively puts this point thus;

Infants would not develop into functioning adults, and society could not continue to exist for more than one generation, without the care of mothering persons; and most people would live rather impoverished lives without the care of the family and friends.

This apparently implies that care is a natural inclination as we care for members of our family and others we love, as indispensable for human survival, we are enjoin to extend care to the domain of morals on the basis of empathy as a duty.

Utilitarianism as a moral model is deficient in terms of what it considers as good and its exclusive consequential motive for actions. It is true that in considering the morality of action, the result of the action should not be ignored, but this is not the only element that should be considered. We must also take into account the nature of the action itself, the intention of the doer, and the circumstances in which s/he acted (Omoregbe, 1993: pp. 3-5).

Care ethics profoundly, takes humanity as a whole into consideration as the means and end towards who pleasure should be directed. The need to realize human good generates the need to harness feminine moral values which care ethics urges us to keep in mind when discharging moral duties. Proponents of care ethics are of the view that moral good is determined by the extent to which it benefits the generality of the people and not the greatest possible number of people. Any moral principle that gives room for partial exclusion of people's interests sets a dangerous precedence as it will be hard to determine the number of voices undermined; and this can generate social unrest as the case with Niger/Delta region in Nigeria, as well as the religions cold war, and the systemic political protests in most parts of the globe and African continent in particular.

Indeed, utilitarian principle is different from care ethics essentially because care is concern about the wellbeing of all, without exception as much as humanly possible. It is contextual and concrete, that is, care is expressed in action having direct bearing on individual lives, unlike the principle of utility which focuses on the application of principle to the neglect of actually attending to the concrete needs of individuals. Application of principles often ignores the suffering or needs of people since a general principle (of whenever A do B) may be inapplicable to a particular situation of no resemblance. This would amount to manipulating people. For instance, it is hard to imagine how the principle of utility can help to solve the problems of poverty among mankind when the rich would always want to pursue and acquire more wealth for their pleasure, creating unbridgeable gap between themselves and the poor which can make life further unbearable for the poor. For care ethics the rich has a responsibility towards the poor by making sure that his wealth impacts positively on the poor and elevates his condition for the better. For instance, if the rich employs the labour of the poor and pays him/her handsome salary, the rich has affected the poor positively.

Utilitarianism could also fail to ensure good governance by zeroing its utility on the possible number of people to the neglect of the minority. Since utilitarianism considers the good of the majority as good enough to generate social integration and happiness, it is prone to danger; for instance, in a corrupt society where corruption is the norm rather than the exception, the concept of majority is hard to determine. How do we determine the majority carries a big question mark? Is it by number, sex, location, prominence, social status, etc.? From experience in Nigeria for example, does the majority not consist of the few fortunate ones who may have ac- 
quired their fortunes at the expense of the less privilege? If whatever is good is determined by the happiness of these few fortunate individuals, it then means, utilitarianism encourages corruption and class distinction in the highest order. In contrast, care ethics is interested on how to meet the needs of everybody in the society. It is about how individuals can channel their happiness and resources toward the well-being, social protection and self determination of others as a means of minimaxing social inequality and promote human development and peaceful co-existence.

It is hard to imagine how the consequences of action alone, under democracy and market economy would be adequate to produce a healthy society. Care, rather than consequences should be the motive for actions. The consciousness of not hurting the feelings of the other person becomes the determinant focus for moral actions. This is because if moral good is determined on the basis of utility, then the happiness of the minority can be sacrificed for the happiness of the said majority. In short, this can explain the tensions, crises and wars ravaging most countries of the world today. The high wave of protests in North Africa currently involving Egypt, Libya, Yemen, Ivory Coast, etc, are demonstrations of discontentment with leaders who do not weigh their happiness and that of their led equally, and invariably unable to be responsible to them on the same footing. Apparently, care ethics discourages segmented happiness in that if a section of the society is deprived or neglected for the said majority, human relationship is most likely to be in jeopardy. For Gilligan, a moral person is one who would decide a moral action or choice by placing oneself and others in a network of relationships involving responsibilities for one another. A truly moral person would always consider others as his/her equal. This means that in a social context, something should be seen to be morally wrong where individuals separately pursue a life of pleasure without minding how it affects the pleasure of others. For care ethics, what should be seen as morally right is a reflection of mutual benefit, a situation where everyone comes out better off (Held, 1995: p. 131).

Whereas utilitarianism concerns itself with the possible number of people affected by a given pleasure, care ethics considers the hurt and benefit an action could impact on others and therefore pay attention to what ought to be done that would help the people involved in the relationship at a particular case at hand (a sense of responsibility). A good illustration of this point is given by Gilligan (1982: pp. 25-26) with the responses of two youths to the question of a moral puzzle involving a man whose wife was critically ill and in danger of dying. A certain drug might save her life, but the man could not afford it, partly because the druggist has set an unreasonable price for it. The question is; whether or not the man should steal the drug. One of the respondents (Jack) answered from utilitarian point of view, considering the utility of the drug to the sick regaining her health and the husband being relieved from the trauma of losing a wife, Jack answered that the man should steal the drug. Apparently, Jack weighed the immediate pleasure to be derived from such action. The second respondent called Amy felt there should be other way out rather than stealing the drug. Her reason for this position could be that she considered the effect of the stealing on all those involved. For the husband, he might save his wife's life through the stolen drug, but if caught might have to go to jail and then the wife might get sicker again. And the druggist could get hurt for losing his drug to theft and a repeat of it could force the druggist out of business and prospective sick people might not get drugs to treat themselves. She rather advises all involved to find a means of reaching mutual agreement concerning how no one is negatively affected in the transaction. This is how care is reflected for oneself and others in moral decision-making process. Such disposition of how an action would affect others strengthens social relationships and enhances social solidarity. It creates a situation whereby everyone is socially protected as Hillary observes:

If everyone on earth behave in a way that showed care for others and courage, the world would be a much better place, you wouldn't have crime and you might not have poverty (Gilligan, 1982: p. 23).

The attitude of care ethics can create in individual minds the need to be responsible to the world at large, that one cannot just live for his/her pleasure alone, but that the fact of being in the world gives one an obligation to do what one can to make the world a better place to live in, no matter how small a scale that may be. Majority of social crimes are generated by a high level of poverty, as the saying goes "a hungry man is an angry man", where care is prevalent poverty is reduced to its barest minimum and crime is scarcely experienced.

The morality of care would help to solve a lot of social problems in contemporary society, particularly the problem of poverty caused by massive corruption, when people who are privilege to manage the affairs of the state begin to realize that they owe others the responsibility of ensuring prevailing opportunity for self determination, the need to serve the people would become glaring and ultimate. Fiona Robinson (2008) had argued overwhelmingly that there may be no better way of addressing the problem of poverty globally except with the attitude and policy of care ethics in contemporary society. Otherwise, why is it that in spite of the efforts 
rights-based and duty-based theorists have made in the area of poverty alleviation, poverty is still more than ever before? This therefore means that individual pleasure in a democratic and market economy cannot translate into a comprehensive better living condition for all.

\section{Conclusion}

The need for mutual benefit in human social relationship defines the necessity for moral principles of behaviour. Expectantly, such benefit should have direct bearing in the living condition of every individual affected. In this regard, it is here argued that the values of care ethics are more noticeable in the productive lives of individual than the application of principle of utility as a basis for social stability. It is not only because utilitarianism adopts principle in the determination of what is morally right and wrong which sways attention from concrete help to those who need help, but also because the principle of utility which advocates pleasure seeking to the avoidance of pains, and the distribution of the pleasure being limited to the possible number of people, has the tendency to sideline, neglect and ignore the needs of others, which on the long run can rob others of their opportunities, as John Locke (1979: pp. 23-51) would say, if a man seeks his pleasure beyond his daily survival he is robbing someone else of what nature has provided equally for them. But when pleasure is sought with the consideration that others need as much pleasure as one, and therefore deliberately impact or enhance others opportunities for pleasure, care is reflected and the essence of living together is strengthened. Therefore, care ethics would fare better as a standard of what should determine the parameters for moral good and bad. Where people care about and for the pleasure of others, individual attitudes and government policies are likely to be people oriented. This would help check corruption, conflicts, wars, poverty and other social vices, and humanity would have more benefits from care ethics than the principle of utility.

\section{References}

Baier, A. (1988). The Need for More than Justice. In M. Hanen, \& K. Nelson (Eds.), Canadian Journal of Philosophy (Vol. 13). Calgary: University of Calgary.

Bentham, J. (1961). An Introduction to the Principles of Morals and Legislation. New York: Doubleday.

Echekwube, A. O. (1999). Contemporary Ethics: History, Theories \& Issues. Lagos: Spero Books Ltd.

Engster, D. (2003). The Political Economy of Care. Annual Meeting of the Annual Political Science Association, Philadelphia Marriott Hotel, Philadelphia. http://www.allacademic.com/meta/p63748_index.html

Frankena, W. (1973). Ethics. Englewood Cliffs, NJ: Prentice-Hall.

Gilligan, C. (1982). In a Different Voice: Psychological Theory and Women's Development. Cambridge, MA: Harvard University Press.

Held, V. (1995). The Meshing of Care and Justice. Hypathia, 10, 128-132.

Hobbes, T. (1909). The Leviathan. Oxford: Clarendon Press.

Jacquette, D. (2004). Pathways in Philosophy: An Introductory Guide with Readings. New York: Oxford University Press.

Lefferrs, M. R. (1993). Pragmatists Jane Addams and John Dewey Inform the Ethics of Care. Hypathia, 8, 64-77.

Locke, J. (1970). Two Treatises of Government. Laslett, P. (Tran). Cambridge: Cambridge University Press.

Machiavelli, N. (1999). The Prince. London: Penguin Books.

Mackinnon, B. (1998). Ethics: Theory and Contemporary Issues (2nd ed.). Belmont, Washington: Wadsworth Publishing Company.

Mill, J. S. (1994). Higher and Lower Pleasures. In P. Singer (Ed.), Ethics. New York: Oxford University Press.

Noddings, N. (2002). Stating at Home: Caring and Social Policy. Berkeley, CA: University of California Press.

Noddings, N. (2003). Caring: A Feminine Approach to Ethics and Moral Education (2nd ed.). Berkeley, CA: University of California Press.

Oladipo, O. (2008). The Need for a Social Philosophy in Africa. Convocation Lecture Delivered at Ambrose Alli University, Ekpoma.

Omoregbe, J. (1993). Ethics: A Systematic and Historical Study (2nd ed.). Lagos: Joja Educational Research and Publishers Ltd.

Sahakian, W. S. (1974). An Introduction to Theories and Problems. New York: Barnes Publishing Company.

Tronto, J. C. (1989). Women and Caring: What Can Feminists Learn about Morality from Caring. In A. M. Jaggar, \& S. R. Bordo (Eds.), Gender/Body/Knowledge: Feminist Reconstrution of Being and Knowing. New Brunswick, NJ: Rutgers University Press. 